\title{
肥満症治療に伴う血小板凝集能の変化と その㐫進機序に関する研究
}

$\begin{array}{lllllll}\text { 川村 光 } & \text { 信* } & \text { 内藤 } & \text { 周 幸* 宮 崎 滋* } \\ \text { 於本 } & \text { 章* } & \text { 川 杉 和 夫* } & & \end{array}$

\section{I. はじめに}

肥満者は単に体重が過剩なだけではなく, Framingham study ${ }^{1)}$ をはじめ, 多くの疫学調査で 知られるように単独でも突然死や冠動脈疾患の発 生の危険因子となる上に, 糖㽷病, 高血圧症, 高 脂血症などを合併することで, さらにそれらの頻 度を増大させている. その上, 内分必系や呼吸器 系疾患などをも併発し易く，医学上，肥満「症」 患者として管理・治療されるべきであると考えら れる ${ }^{2}$.こうした考えに基づき，われわれは，明 らかな心電図異常や動脈硬化性疾患の合併が認め られない肥満症患者に長期閒の超低カロリー食 (半飢餓) 療法を行い, 体重減少をもたらした。 体重減少により, 動脈硬化の危険因子が軽減され るという予測の下に, その判定指標の 1 つとして 血小板凝集能を測定したところ，予測に反して， 治療前に比べて, 治療後に大部分の症例において 凝集能の立進がみられた. 血小板凝集能は, 冠動 脈疾患をはじめとする動脈硬化性疾患で立進する ことが知られており ${ }^{3)}$ ，この予測に反した成績を 検討・解明することは, 肥満症患者の安全な減量 治療法を確立する上で有意義であると思われた.

* 東京聥信病院内科

原稿受取日：1989年 3 月 8 日

採用決定日：1989 年 8 月 23 日

\section{II. 方 法}

\section{1. 臨床および基礎実験の方法}

1）肥満症患者の半飢餓療法に伴う血小板凝集 能の変化

対象は昭和 55 年 6 月より昭和 63 年 4 月までに東 京逓信病院に入院して来た肥満症患者 46 名で, い ずれも Broca 変法) (身長から 100 を減じた值に 0.9 を乗じた值を標準体重とし，実測体重を標準 体重で除した百分率から 100 を減じた值を肥満度 とする）によって，肥満度が $+25 \%$ 以上であった。

入院後一部の症例を除いて $1,200 \mathrm{kcal} /$ 日の食事 を椇取しながら，血小板凝集能をはじめとする各 種の検査を行った. その後 $400 \mathrm{kcal} /$ 日の半飢餓 療法を 4 週間以上行った。一部の症例では $\mathrm{T}_{3}(\mathrm{~L}-$ Triiodothyronine) $75 \mu \mathrm{g} /$ 日 を併用した。その後一 部の症例を除いて退院前に再び $1,200 \mathrm{kcal} /$ 日の食 事摂取にもどして半飢餓療法開始前と同様の検査 を行った. $1,200 \mathrm{kcal}$ 食の内容は，糖質 $149 \mathrm{~g}$, 蛋 白質 $60 \mathrm{~g}$, 脂質 $40 \mathrm{~g}(\mathrm{P} / \mathrm{S}$ 比 0.7〜0.8) であり, 400 $\mathrm{kcal}$ 食は主に Optifast ${ }^{\circledR}$ を用いた。また，血小板 凝集能検査と血清遊離脂肪酸 (FFA) の測定は, いずれも $1,200 \mathrm{kcal}$ 食開始および再開 2 日目に 行った. 採血は全て12時間絶食にした早朝空腹時 に行い, 実験は午前 9 時に開始した.

2) Norepinephrine 持続静注による FFA の変 動と血小板凝集能の変化

健常成人男性 10 名を対象とし, 持続注入ポンプ を用いて norepinephrine $0.1 \mu \mathrm{g} / \mathrm{min} / \mathrm{kg}$ 体重の 
割合で 30 分間持続注入5) し，その前後における血 清 FFA と血小板凝集能とを測定した.

3） In vitroにおける血漿・血小板の交換実験 による血小板凝集能の検討

対象は 4 週間以上の半䶿餓療法を受けた肥満症 患者 7 名とそれぞれの患者に $\mathrm{ABO}$ 式および $\mathrm{Rh}$ 式血液型が合致する健常成人対照者である.これ らの対象者間において血漿と血小板を相互に in vitro で交換し，血小板凝集能の変化を検討した.

4） $\mathrm{Ca}$ 濃度の変化による血小板凝集能の検討

In vivo の実験健常成人男性 2 名と健常成人 女性 2 名を対象にして行った．各対象者に早朝空 腹時 calcium glucuronate $7 \mathrm{mg} / \mathrm{kg}$ 体重を 10 分閒 かけて静注し，投与前および投与 30 分後の遊離 $\mathrm{Ca}$ と血小板凝集能を測定した.

In vitro の実験は，同様の対象者より洗浄血小 板浮遊液を作成し，血小板凝集能におよぼす $\mathrm{Ca}$ 添加量の影響を検討した。

5) In vitro における，1,2-diacylglycerol (1oleoyl-2-acetyl-glycerol; 1,2-DG，フナコシ薬 品）の血小板凝集能におよぼす影響

$\mathrm{Ca}$ 負荷実験を行った同一対象者より乏血小板 血漿 (platelet-poor plasma；PPP) で血小板数を調 整した多血小板血漿 (platelet-rich plasma; PRP) を作成して，1,2-DG を添加し，これに血小板凝 集若起作用があるか否かを検討した.

次いで，1,2-DG を血小板数を調整した PRP と 孵置した後に，各種の凝集惹起物質による血小板 凝集能を測定し，それに影響があるか否かを検討 した.

6) 肥満症患者の半飢餓療法前後における血清

FFA の脂肪酸分画の検討

肥満症患者 6 名を対象とし，半飢餓療法前後に おける血清 FFA の脂肪酸分画, 特に eicosapentaenoic acid ( $\left.\mathrm{C}_{20: 5} \omega_{3}, \mathrm{EPA}\right)$, docosahexaenoic acid $\left(\mathrm{C}_{22: 6} \omega_{3}, \mathrm{DHA}\right)$, arachidonic acid $\left(\mathrm{C}_{20: 4} \omega_{6}, \mathrm{AA}\right)$ について検討した.

\section{2. 分析および測定方法}

血液および血液生化学検査は，本院の臨床検査 室において標準化している自動分析器によって測 定した (血清脂質のうち， total cholesterol (TC), triacylglycerol (TG) は酵素法で測定した). High density lipoprotein-cholesterol (HDL-ch) は Heparin・Ca 沈澱法6) で測定した. FFA は血清 $1 \mathrm{~m} l$ よりDole 法によって FFA を抽出し, 滴定法を用 いて測定した7)。遊離 $\mathrm{Ca}$ は，総 $\mathrm{Ca}$ を測定した 後 Payne の補正式8) を使用して算出した. Epinephrine, norepinephrine, dopamine は高速液体ク ロマトグラフィー法9)で, thromboxane (TX) $\mathrm{B}_{2}{ }^{10}$ ) と 6-keto-prostagladin (PG) $\left.\mathrm{F}_{1 \alpha}{ }^{11}\right)$ はラジオイム ノアッセイ法で測定した.

Ex vivo の血小板凝集能は以下のようにして測 定した。まず，対象者を一夜絶食にした早朝空腹 時に，3.8\%のクエン酸ナトリウムを $1 / 10$ 容量加 えて採血した血液を $22^{\circ} \mathrm{C}$ で $300 \times \mathrm{g}, 6$ 分間遠心し て，その上清を採取して PRP とし，残りの血液 を $22^{\circ} \mathrm{C}$ で $800 \times \mathrm{g}, 15$ 分間遠心して，その上清を採 取してPPP とした ${ }^{12)}$ 。 そしてPRPをPPPで稀 釈し, 血小板数を $(27-30) \times 10^{4} / \mu l$ に調整し，こ の数を調整した PRP $350 \mu l$ にルシフェリン・ル シフェラーゼ (L.L.) $40 \mu l$ を添加し， その後スタ ラーバーを入れて攪拌した後, 凝集惹起物質を加 えて凝集を惹起し，クロノログ・ルミアグリゴメ ーターで測定した ${ }^{13)}$. 凝集惹起物質としては ADP, epinephrine, collagen を用い，ATP の放出反応に よって二次凝集の有無を確認して二次凝集を薏起 する最低濃度を閾值濃度として判定を行った。ま た一部の実験では特定の凝集惹起物質での，一定 の最終濃度による最大凝集率についても判定を行 った.

血小板の洗浄は以下のようにして行った. 一夜 絶食にした対象者から早朝空腹時, 前述した方法 で採血し，PRP とPPP を作成した.このPRP に $1 / 10$ 容量の ACD 液および EDTA (最終濃度 1 $\mathrm{mM})$ を加え, $22^{\circ} \mathrm{C}$ で $800 \times \mathrm{g}, 15$ 分間遠心して洗 浄した後, 上清を捨てて沈澱した血小板を $15 \mathrm{mM}$ 等張卜リス緩衝液 (A) $(0.134 \mathrm{M} \mathrm{NaCl}, 5 \mathrm{mM}$ glucose, 1 mM EDTA を含む. PH 6.5) に浮遊し, さらに $22^{\circ} \mathrm{C}$ で $800 \times \mathrm{g}, 15$ 分間遠心し再度洗浄し た. 再び上清を捨て, 再度 $15 \mathrm{mM}$ 等張トリス緩 衝液 (A) による洗浄を行った.その上清を捨てて, 2 回洗浄血小板を作成した.

In vitro に掞ける血漿・血小板の交換実験では, 洗浄血小板を健常成人対照者および肥満症患者 
の PPP に再浮遊し, Coulter counter (日科機, Model ZBI) で血小板数を $(30 \pm 5) \times 10^{4} / \mu l$ 亿調整 した ${ }^{14,15)}$. この数を調整した洗浄血小板浮遊液 $300 \mu l$ に L.L. $30 \mu l$ と Ca の最終濃度が $2 \mathrm{mM}$ と なるように $\mathrm{CaCl}_{2}$ を添加し， $\mathrm{ADP}$ 凝集 (最終濃 度 $1,3,5 \mu \mathrm{M})$, epinephrine 凝集 (最終濃度 1,3 , $5 \mu \mathrm{M}$ ) および collagen 凝集 (最終濃度 $0.5,1,2,3$ $\mu \mathrm{g} / \mathrm{m} l)$ を測定し，最大凝集率の判定を行った．採 用した最終濃度は，各人の血小板を各人の血漿に 浮遊させて凝集を惹起させた時に二次凝集を生じ る最低濃度とした。

In vitro での $\mathrm{Ca}$ の血小板凝集能に対する影響 を検討した実験は，前述した方法で 2 度洗浄した 洗浄血小板を $15 \mathrm{mM}$ 等張卜リ又緩衝液 $(\mathrm{B})(0.134$ $\mathrm{M} \mathrm{NaCl} ， 5 \mathrm{mM}$ glucose を含む. PH 7.4) に血小 板が $(30 \pm 5) \times 10^{4} / \mu l$ となるように再浮遊させ， 洗浄血小板浮遊液を作成した後, この洗浄血小板 浮遊液 $300 \mu l$ に Ca の最終濃度が $0,1,2,4 \mathrm{mM}$ となるように $\mathrm{CaCl}_{2}$ を添加し， L.L.を $30 \mu \mathrm{l}$ 加 えた後, thrombin 凝集 (最終濃度 $0.5,1 \mathrm{U} / \mathrm{ml}$ ) の 最大凝集率を検討した。

In vitro の 1,2-DG の添加実験は血小板を (2730) $\times 10^{4} / \mu l$ に調整した PRP に L.L. を $30 \mu l$ 入れ た後, 1,2-DG の最終濃度が $0.04,0.1,0.4 \mu \mathrm{g} / \mathrm{m} l$ となるようにこれを添加し，血小板凝集がおこる か否かを検討した. さらにこの PRP $300 \mu l$ に最 終濃度が $0.04,0.1,0.4 \mu \mathrm{g} / \mathrm{m} l$ となるように $1,2-$
DG を添加した後， 1 分間 preincubation し L.L. を $30 \mu l$ 加えて, ADP 凝集 (最終濃度 $3 \mu \mathrm{M}$ ), epinephrine 凝集 (最終濃度 $3 \mu \mathrm{M}$ ) および collagen 凝集 (最終濃度 $2 \mu \mathrm{g} / \mathrm{m} l$ ) の最大凝集率を検討した。

血清 FFA の脂肪酸分画は血清 $1 \mathrm{~m} l$ より Trout の方法 ${ }^{16)}$ で FFA を抽出した後, エステル化して キャピラリーカラムクロマトグラフィー(島津 GC-6A-PRF) で測定した ${ }^{17,18)}$ 。この方法により， EPA，DHA，AA は完全に分離・同定することが できた.

\section{III. 結 果}

Figure 1 に示すように，血小板凝集能は ADP, epinephrine, collagen のいずれを凝集惹起物質と して用いた場合にも，半飢餓療法前に比べて，治 療後において有意に立進した。特に ADP 凝集お よび epinephrine 凝集において京進の程度は著し かった. Table 1 に半飢餓療法開始前および後の 各種血液生化学と尿生化学検査の変化を示した. Albumin および各種脂質成分は血清 FFA 以外は 全て治療前に比して, 後では低下を示した. 血清 FFA は治療前に比して，後で上昇する傾向 $(\mathbf{P}<$ 0.1）がみられたが，有意ではなかった。しかし， 血清 FFA/albumin 比は治療後に有意の上昇を示 した，血液および尿中の catecholamine 類は，治 療前に比して，後においてほとんどのものが有意 に低下したが，血漿 epinephrine 拉よび尿中

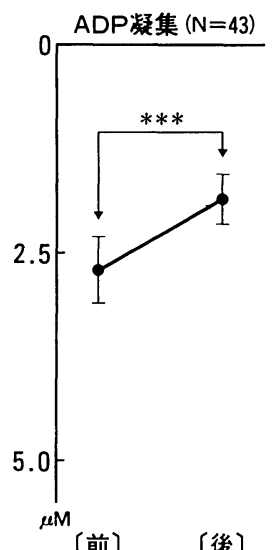

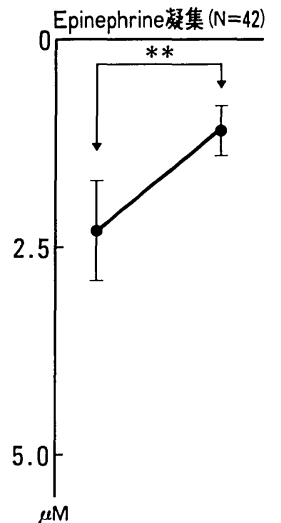

〔前〕〔後〕

Mean \pm SE

$* ; \mathrm{P}<0.05, * * ; \mathrm{P}<0.02, * * * ; \mathrm{P}<0.01$

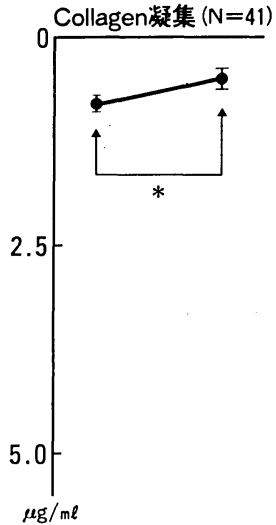

〔後〕

Fig. 1 肥満症患者の半飢餓療法前後の血小板凝集能の变化. 
dopamine には変化がみられなかった. 血漿 PG 類, すなわち $\mathrm{TXB}_{2}$ および 6-keto-PGF ${ }_{1 \alpha}$ にはともに 有意な変化はみられなかった. 血清 FFA/albumin 比と各種凝集惹起物質による血小板凝集能（閾值 濃度）との間には相関はみられなかったが，Fig. 2 に示したように，血清 FFA/albumin 比の変動 量と ADP による血小板凝集能の変化量との間に

Table 1 肥満症患者の半飢餓療法前後の血液および尿 生化学検査

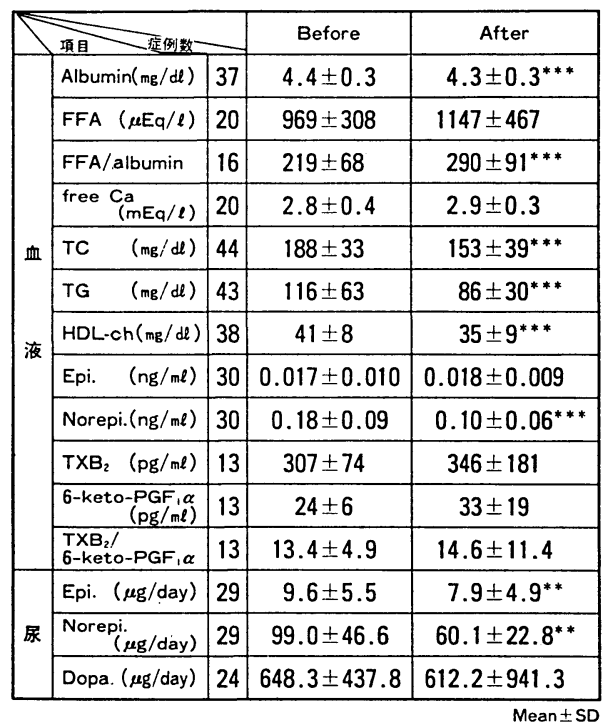

FFA ; free fatty acid, TC ; total cholesterol,

TG ; triacylglycerol, HDL-ch; high density lipoprotein-cholesterol

Epi.; epinephrine, Norepi.; norepinephrine, TXB ${ }_{2}$; thromboxane $B_{2}$

6-keto-PGF, $\alpha ; 6$-keto-prostaglandin $F_{1} \alpha$, Dopa.; dopamine

$* * ; \mathrm{P}<0.02, \quad * * * ; \mathrm{P}<0.01$
は, $\mathrm{r}=-0.583(\mathrm{P}<0.05)$ と弱い負の相関がみられ た. Epinephrine 凝集および collagen 凝集では変 化量についても相関はみられなかったが，血清 FFA の変動が血小板凝集能の変化に関与してい るか否かをさらに検討するために norepinephrine 少量持続静注試験を行った．Fig. 3 に示すように， norepinephrine 持続静注後血清 FFA は全例で著 明に上昇したが，閾值濃度で判定した血小板凝集 能にはほとんど変化がみられなかった。

そのため, 次に半飢餓療法後の血小板凝集能の 立進をもたらす要因が主として血漿に存在するの か，あるいは血小板に存在するのかを検討するた めに， in vitro における血漿・血小板の交換実験 を行った. Fig. 4 の左図 (A) に示すように, 健常 成人対照者洗浄血小板を健常成人対照者血漿に再 浮遊した場合と肥満症患者血漿に再浮遊した場合 とを比較すると ADP 凝集で患者血漿に再浮遊し た場合の方が凝集能の有意な元進がみられた。 Epinephrine 凝集，collagen 凝集でも同様の傾向 がみられたが，有意ではなかった。一方，Fig. 4 (B) に示すように，患者洗浄血小板を対照者血漿 と患者血漿に再浮遊した場合との比較では，対照 者血漿に再浮遊した場合より患者血漿に再浮遊し た場合の方が ADP 凝集に招いて有意の充進がみ られた. Epinephrine 凝集および collagen 凝集で も同様の傾向がみられたが有意ではなかった。こ の in vitroに打ける血漿・血小板の交換実験から

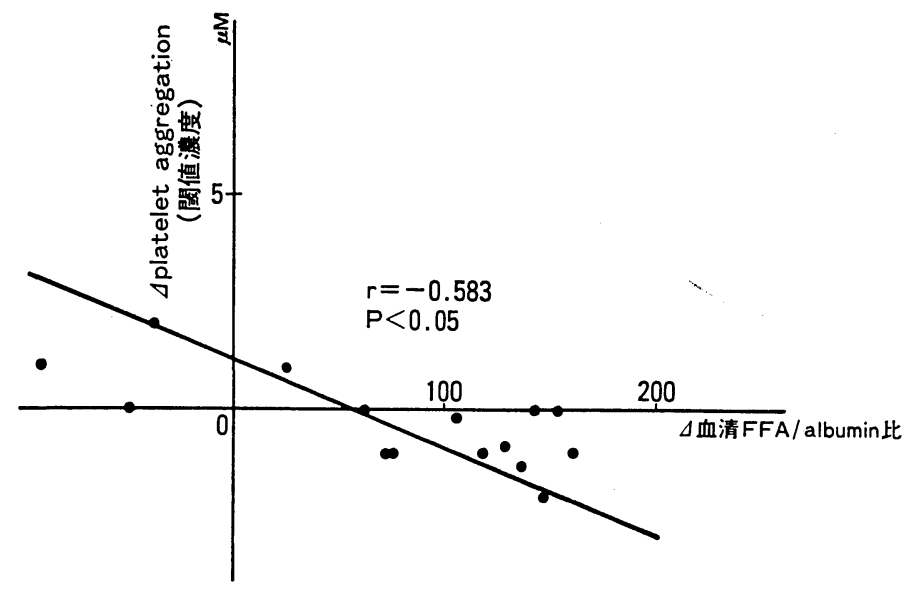

Fig. 2 肥満症患者の半飢餓療法に伴う血清 FFA/albumin 比の変動量と血小板凝集能 (ADP 凝集) の変化量. 


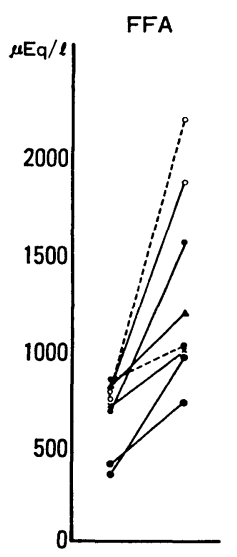

〔前〕〔後〕

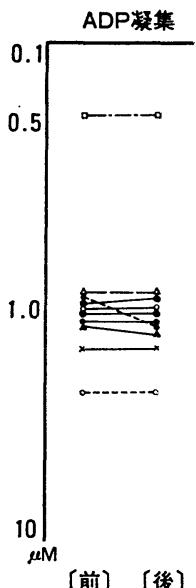

〔前〕〔後〕

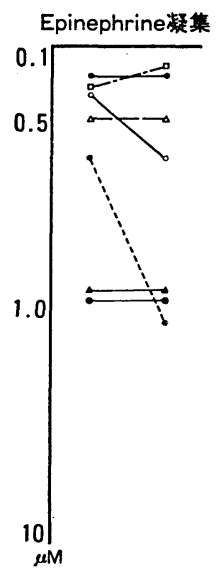

〔前〕〔後〕

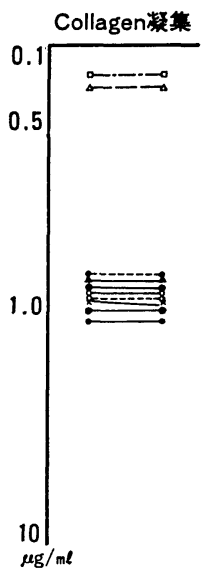

[前〕〔後〕

Fig. 3 Norepinephrine 持続静注 $(0.1 \mu \mathrm{g} / \mathrm{min} / \mathrm{kg}) 30$ 分後の血清 FFA の变動と血小板凝集 能 (閾值濃度)の変化.

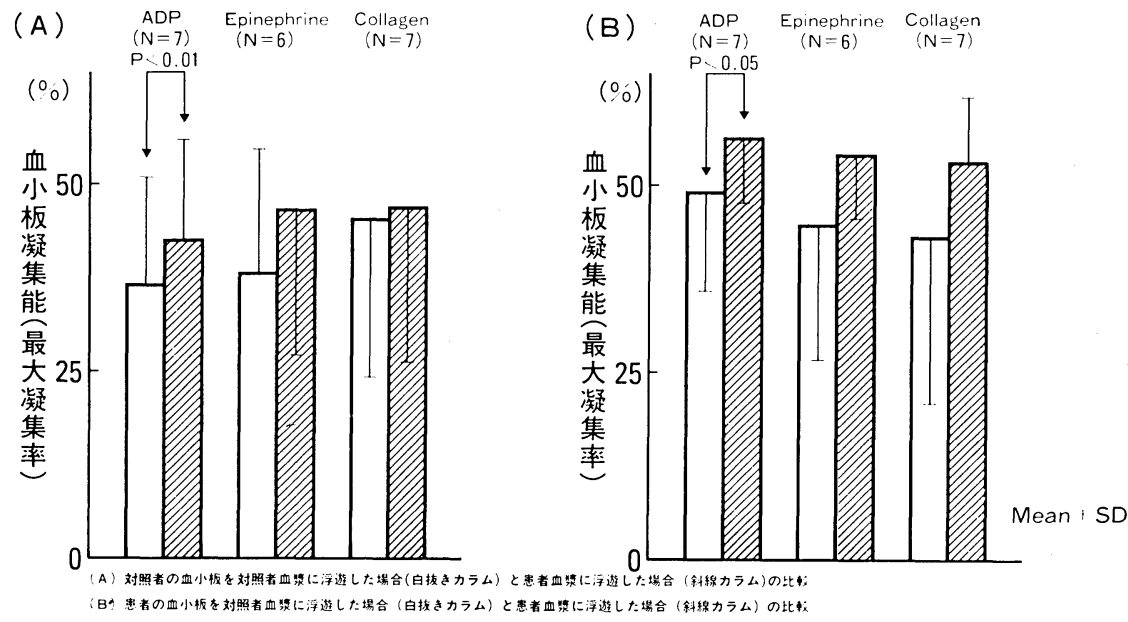

Fig. 4 健常成人対照者と肥満症患者 (半飢餓療法終了後) の血漿・血小板交換実験.

血小板凝集能の立進を促す因子は主として血漿に 存在することが示唆された.

In vivo における Ca 負荷では, $\mathrm{Ca}$ 負荷後遊離 $\mathrm{Ca}$ は $0.15 \pm 0.05 \mathrm{mEq} / l$ の上昇を示したが，閾值 濃度で判定した血小板凝集能には差がみられなか った。また, in vitroの $\mathrm{Ca}$ 添加実験で $\mathrm{Ca}$ の最終 濃度が $0 \mathrm{mM}$ の場合には血小板凝集は惹起され なかった.さらに，1,2,4 $\mathrm{mM}$ の場合には，これ らの間で最大凝集率によって判定した血小板凝集 能に差はみられなかった。

PRP を用いた in vitro での 1,2-DG の添加実験 により，1,2-DG は単独では，血小板凝集惹起作
用がないこと，また 1,2-DG をPRP と preincubation した後, 各種の凝集惹起物質により凝集を惹 起したが，これらの凝集にも影響をおよぼさない ことが判明した.

肥満症患者の半飢餓療法前後に抒ける血清FFA の脂肪酸分画の検討では, Table 2 に示すように EPA/AA 比は 6 例中 4 例において低下し，EPA +DHA/AA 比は 5 例において低下した。

\section{IV. 考 案}

肥満症は単に太っているだけではなく, 種々の 合併症をきたすため肥満症患者として取り扱われ 
動脈硬化 Vol. 17 No. 41989

Table 2 肥満症患者の半飢餓療法前後の血清 FFA 中 の脂肪酸組成と血小板凝集能の変化

\begin{tabular}{|c|c|c|c|c|c|}
\hline & \multicolumn{2}{|c|}{ Serum FFA } & \multicolumn{3}{c|}{$\begin{array}{c}\text { Platelet aggregation } \\
(\text { 閥 }\end{array}$ 值 濃度) } \\
\hline 1 & -0.63 & -1.16 & -1.3 & -8 & -0.5 \\
\hline 2 & -0.08 & -0.73 & -2 & -1.8 & -1.8 \\
\hline 3 & -0.06 & -0.39 & -1 & -0.4 & -0.8 \\
\hline 4 & -0.04 & -0.22 & -1 & -3.5 & -1.5 \\
\hline 5 & 0.00 & -0.47 & 0 & 0 & -0.2 \\
\hline 6 & +0.02 & +0.20 & -0.2 & 0 & +0.3 \\
\hline
\end{tabular}

\&. 变化量(後值から前値を引いた值)を表わす。

るべきであるという考え方がわが国でもようやく 定着しつつある ${ }^{2)}$. この肥満症患者に対する減量 療法前後における様々な生化学的変化についての 報告はいくつかみられる ${ }^{19)}$.また，これまで, 正 常健常人の数日間の絶食前後における血小板凝集 能についての検討はなされている20,21) が，肥満 症患者の長期におよぶ半飢餓療法前後での検討は みられない，そのためわれわれは今回，動脈硬化 性疾患で立進することが知られている血小板凝集 能が肥満症の治療前に比べて, 治療後に低下する のではないかという予測の下に半飢餓療法前後に おける検討を行った。 しかし，Fig. 1 に示したよ うに, 治療後に打ける血小板凝集は, ADP, epinephrine, collagen のいずれを凝集若起物質として 用いた場合でも，治療前に比して有意な九進を示 した。この予測に反した成績を解明するために， 肥満症患者の治療前後における各種の血液および 生化学的検查を比較検討した. Table 1 に示した ように, 動脈硬化の促進因子と考えられるほとん ぞの脂質成分は治療後に低下したが，FFA は上 昇する傾向を示した。 また albumin は有意に低 下し, 結果的に血清 FFA/albumin 比は有意な上 昇を示した。 FFA は細胞毒性が強い上， in vitro の実験では血小板凝集を若起することが知られて おり ${ }^{15)}$ ，また albumin は生体内では FFA の担体 として働くため FFA の細胞毒性を緩和したり， 血小板凝集を抑制する方向に作用すると思われ $ろ^{22)}$. また, 加齢や糖尿病において血漿 FFA/albu$\min$ 比が上昇し, 動脈硬化の進展を促進する傾向 がみられるとの報告もあり ${ }^{23,24)}$, 肥満症患者の治 療に伴ってこの比が上昇することは，血小板凝集
能の充進とも関連して，きわて興味が持たれる.

しかし，血清 FFA/albumin 比と各種凝集若起 物質による血小板凝集能の間には相関はみられず, 血清 FFA/albumin 比の変動量と血小板凝集能の 変化量との間には ADP を用いた時にのみ弱い負 の相関がみられたが， epinephrine 凝集や collagen 凝集ではこの場合にも相関はみられなかった。そ こで, さらに健常成人男性に norepinephrine 0.1 $\mu \mathrm{g} / \mathrm{min} / \mathrm{kg}$ 体重の割合で持続静注を行い，血小板 凝集能の変化を検討した. Fig. 3 に示したように 血清 FFA は速やかに上昇したが，血小板凝集能 にはほとんど変化がみられなかった。この成績は， 肥満症患者の治療に伴う血小板凝集能の六進には, 血清 FFA の増加や血清 FFA/albumin 比の変動 が一次的には関与していないことを示唆している と思われた. Laustiola ら ${ }^{25)}$ は，健常成人に対し て epinephrine を 60 分間持続静注した前後におけ る血小板凝集能を検討しているが，静注前と静注 60分後の間では血小板凝集能に差がなく, 静注中 止60分後に, 静注前に比して充進していることを 示した. この時点においては血清 FFA はすでに 低下して元に復しているが，彼らはこの際の血小 板凝集能の元進は $\mathrm{TXB}_{2}$ の産生元進によると述 べている.しかし， Table 1 に示したように，肥 満症患者の治療前後では， $\mathrm{TXB}_{2}$ および 6-keto$\mathrm{PGF}_{1 \alpha}$ に差は見られなかった。

この血小板凝集能の亢進を促す因子が主として 血漿に存在するのか, 血小板に存在するのかを検 討するため, 健常成人対照者と肥満症患者閒で, in vitroに扔ける血漿・血小板の交換実験を行っ た. Fig. 4 に示したように，対照者および患者の いずれの洗浄血小板を用いた場合でも，患者血漿 に浮遊させた際の方がより凝集能の充進がみられ， 治療に伴う凝集能の亢進因子は主として血漿に存 在することが示唆された.

そのため second messengerとして注目されてい るCa+126) の in vivo での負荷および in vitro で の添加試験, 1,2-DG ${ }^{27)}$ の in vitro での添加試験 を行ったがいずれでも血小板凝集能に変化はみら れなかった. これらの他に血小板機能，特に凝集 能に大きな影響をおよぼす可能性のあるものとし て, 脂肪酸が考えられる ${ }^{28)}$. 洗浄血小板を使用し 
た in vitroの実験から特に遊離型の脂肪酸は容易 に血小板に取り込まれて血小板凝集能に影響を与 えることが知られている12). もし生体内において も同じようなことが起こっているとすれば，生体 内における turn-over の速さや濃度の変動性から 考えて，FFA は生体内でも血小板機能に影響を 与える重要な因子になると考えられる。しかしわ れわれの実験の範囲ではこの仮説を明瞭に証明す ることができず，わずかに血清 FFA/albumin 比 の変動量と ADP 凝集変化量の間の弱い相関が多 少血清 FFA の重要性を示唆したにとどまった.

一方，近年，血小板機能の抑制作用が強い脂肪 酸として $\mathrm{EPA}^{29,30)}$ や $\mathrm{DHA}^{31)}$ が注目されている.

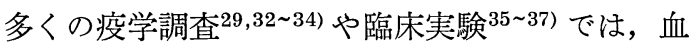
漿(清) および／または血小板 EPA/AA 比や EPA + DHA/AA 比が上昇すると血小板凝集能が低下 することが 報告されている． Table 2 に示したご とく, 肥満症患者の治療における血清 FFA の脂 肪酸分画の分析では，治療後には治療前に比べて 6 例中 4 例において EPA/AA 比の低下と 5 例にお ける EPA+DHA/AA 比の低下がみられ，この比 の低下の著しい患者ほど血小板凝集能がより克進 する傾向がみられた。このことは, 肥満症患者の 減量による血小板凝集能の六進には，血清 FFA の量の増加よりはむしろ，その FFA の脂肪酸 pattern の変化が直接的，間接的に関与している ことを示していると考えられた．今後さらに，本 治療に伴う血小板凝集能を充進させる因子を同定 するための検討が必要と思われる.

\section{V. 結 論}

肥満症患者に対する長期半飢餓療法に伴う各種 パラメータを比較検討し, 治療前に比べて, 治療 後に血小板凝集能が充進するという新知見を見い だした。その事実を解明するためにいくつかの実 験を行い, 以下の結論を得た。

1) 肥満症治療に伴う血小板凝集能 (ADP凝集) の変化量と血清 FFA/albumin 比の変動量の間に は弱い負の相関が見られたが，原因・結果的な相 関とは考えられなかった。

2) 健常成人に対する少量 norepinephrine の持 続静注においては，血清 FFA の増加にもかかわ
らず，血小板凝集能に変化はみられなかった．

3）健常成人対照者と肥満症治療患者との in vitroにおける血墏・血小板の交換実験から治療 後における血小板凝集能の元進を促す因子は, 主 として血漿にあることが示唆された。

4）肥満症患者の治療後に血清 FFA の脂肪酸 分画での EPA/AA 比, EPA+DHA/AA 比の低下 の著しい患者では, 血小板凝集能の克進がより著 しかった。

以上の結果より, 肥満症患者の半飢餓療法後の 血小板凝集能の亢進には, 血清 FFA の量の増加 よりはむしろ, FFA 脂肪酸 pattern の変化が関 与していると思われた。

\section{文献}

1) Hubert, H. B., Feinleib, M., McNamara, P. M. and Castelli, W. P.: Obesity as an independent risk factor for cardiovascular disease: A 26-year followup of participants in the Framingham Heart Study. Circulation, 67: 968-977 (1983).

2) 内藤周幸 : 「症」としての肥満. からだの科学, 105: 34-38 (1982).

3) Ross, R. and Glomset, J. A.: The pathogenesis of arteriosclerosis. N. Engl. J. Med., 295: 369-376, 420-425 (1976).

4) 宮崎 滋：肥満の定義と判定. からだの科学，105: 39-44 (1982).

5) 内藤周幸 : 肥満細胞の反応性と肥満症. ホルモンと 臨床, 28: 501-509 (1980).

6) Burstein, M., Scholnick, H. R. and Morfin, R.: Rapid method for the isolation of lipoprotein from human serum by preceptation with polyanions. J. Lipid Res., 11: 583-595 (1970).

7) Dole, V. P.: A relation between non-esterified fatty acids in plasma and the metabolism of glucose. J. Clin. Invest., 35: 105-154 (1956).

8) Payne, R. B., Little, A. J. and Williams, R. B.: Interpretation of serum calcium in patients with abnormal serum proteins. Brit. Med. J., 5893: 643-646 (1973).

9) Hjemdahl, P.: Catecholamine measurements by high-performance liquid chromatography. Am. J. Physiol., 247: E13-E20 (1984).

10) Vinnikka, L. and Ylikorkala, O.: Measurement of thromboxane $\mathbf{B}_{2}$ in human plasma of serum by radioimmunoassay. Prostaglandins, 20: 759-766 (1980).

11) Skrinska, V. and Lucas, F. V.: Isolation of prostacyclin from whole blood. Prostaglandins, 22: 365-375 (1981).

12）内藤周幸, 橋本佳明, 川村光信 : 血小板と脂質. 動 
脈硬化，12: 1359-1369 (1985).

13) Feinman, R. D., Lubowsky, J., Charo, I. and Zabinski, M. P.: The lumiaggregometer: A new instrument for simultaneous measurement of secretion and aggregation by platelet. J. Lab. Clin. Med., 90: 125-129 (1977).

14) Hashimoto, Y., Naito, C., Kawamura, M. and Oka, H.: Effects of the ratio of exogenous eicosapentaenoic acid to arachidonic acid on platelet aggregation and serotonin release. Thromb. Res., 34: 439-466 (1984).

15）内藤周幸, 川村光信, 橋本佳明: 多価不飽和脂肪酸 と血小板機能. 動脈硬化, 11: 239-250 (1983).

16) Trout, D. L., Estes, E. H., Jr. and Friedberg, S. J.: Tritration of free fatty acids of plasma; A study of current methods and a new modification. J. Lipid Res., 1: 199-202 (1960).

17) Morrison, W. R. and Smith, L. M.: Preparation of fatty acid methylesters and dimethylacetals from lipid with baron fluoride-methanol. J. Lipid Res., 5: 600-608 (1964).

18）日比野英彦, 福田信雄, 工藤喜代志, 川村光信, 内 藤周幸 : 短ガラスキャピラリーガスクロマトグラフ イーによる血液脂質中の多価不飽和脂肪酸の迅速測 定法. 油化学, 33: 625-627 (1984).

19) Hoffer, L. J., Bistrian, B. R., Young, V. R., Blackburn, G. L. and Matthews, D. E.: Metabolic effects of very low calorie weight reduction diets. J. Clin. Invest., 73: 750-758 (1984).

20) Gjesdal, K., Nordøy, A., Wang, H., Berntsen, H. and Mjøs, O. D.: Effects of fasting on plasma and platelet-free fatty acids and platelet function in healthy males. Thrombos. Haemostas., 36: 325333 (1976).

21) Goodnight, S. H., Inkeles, S. B., Kavach, N. L. and Connor, W. E.: Reduced prostacyclin survival after fasting-induced elevation of plasma fatty acids. Thrombos. Haemostas., 54: 418-421 (1985).

22）内藤周幸, 川村光信, 橋本佳明：血小板と EPA. 血 小板 1987 - 血小板と脂質——. 科学評論社, 東 京, 1987, pp. 189-205.

23) Dondona, P.: Plasma non-esterified fatty acid levels and atherogenesis in diabetes mellitus. Diabetologia, 21: 499-500 (1981).

24) Pickart, L.: Increased ratio of plasma free fatty acids to albumin during normal aging and in patients with coronary heart disease. Atherosclerosis, 46: 21-28 (1983).
25) Laustiola, K., Kaukinen, S., Seppala, E., Jokela, T. and Vapaatalo, H.: Adrenaline infusion evokes increased thromboxane $B_{2}$ production by platelets in healthy men: The effect of betaadrenoreceptor blockade. Eur. J. Clin. Invest., 16: 473-479 (1986).

26) Rasmussen, H.: The calcium messenger system. N. Engl. J. Med., 314: 1094-1101, 1164-1170 (1986).

27) Rink, T. J., Sanchez, A. and Hallan, T. J.: Diacylglycerol and phorbol ester stimulate secretion without raising cytoplasmic free calcium in human platelets. Nature, 305: 317-319 (1983).

28) Spector, A. A. and Yorek, M. A.: Membrane lipid composition and cellular function. J. Lipid Res., 26: 1015-1035 (1985).

29) Dyerberg, J., Bang, H. O., Stofferson, E., Moncada, S. and Vane, J. R.: Eicosapentaenoic acid and prevention of thrombosis and atherosclerosis? Lancet, II: 117-119 (1978).

30) Sinclair, H.: Advantages and disadvantages of an Eskimo diet. In: Drugs affecting Lipid metabolism (edit. Fumagalli, R., Kritcheusky, D., Paoletti, R.). Elsevier, North-Holland, 1980, pp. 363-370.

31) von Schacky, C. and Weber, P. C.: Metabolism and affects on platelet function of the purified eicosapentaenoic and docosahexaenoic acids in humans. J. Clin. Invest., 76: 2446-2450 (1985).

32) Dyerberg, J., Bang, H. O. and Hjørne, N.: Fatty acid composition of the plasma lipids in Greenland Eskimos. Am. J. Clin. Nutr., 28: 958-966 (1975).

33) Sanders, T. A. B., Naismith, D. J., Haines, A. P. and Vicker, M.: Cod-liver oil, platelet fatty acids, and bleeding time. Lancet, I: 1189 (1980).

34) Dyerberg, J. and Bang, H. O.: Haemostatic function and platelet polyunsaturated fatty acids in Eskimo. Lancet, II: 433-435 (1979).

35) Thorngren, M. and Gustafson, A.: Effects of 11week increase in dietary eicosapentaenoic acid on bleeding time, lipids, and platelet aggregation. Lancet, II: 1190-1193 (1981).

36) Goodnight, S. H., Jr., Harris, W. S., Conner, W. E.: The effects of dietary $\omega-3$ fatty acids on platelet composition and function in man: A prospective, controlled study. Blood, 58: 880-885 (1981).

37) Siess, W., Roth, P., Scherer, B., Kurzmann, I., Bohling, B. and Weber, P. C.: Platelet-membrane fatty acids, platelet aggregation, and thromboxane formation during a mackerel diet. Lancet, I: 1189 (1980). 


\title{
Summary \\ Increase of Platelet Aggregability in Association with Long-term Semi-starvation Therapy for Obesity and the Mechanism of the Increase
}

\author{
Mitsunobu Kawamura, Chikayuki Naito, Shigeru MiYazaki, \\ Akira Омото and Kazuo KawaSUGI
}

Department of Internal Medicine, The Tokyo Teishin Hospital, Tokyo Japan

We serially examined changes of blood chemistry and urinary constituents in association with longterm semi-starvation therapy (400 kcal/day) for obesity. We found a new phenomenon that platelet aggregability increased after semi-starvation therapy. To clarify the mechanism of the increase of platelet aggregability we performed several experiments. The results are as follows:

(1) There was a weak negative correlation between the difference before and after semi-starvation therapy in platelet aggregability (ADPinduced platelet aggregation) and that in the plasma free fatty acid (FFA)/albumin ratio. However, the correlation did not seem to have a cause and effect relationship.

(2) When a low dose of norepinephrine was continuously infused into healthy subjects, the plasma FFA concentration increased in all subjects, but platelet aggregability did not change consistently.

(3) It was suggested by in vitro experiments, in which platelets obtained from the obese patient subjected to semi-starvation therapy were suspended in plasma obtained from the healthy subject and vice versa, that there are some factors in plasma which increase platelet aggregability.

(4) There was a more marked increase of platelet aggregability in obese patients who showed a more marked decrease in the ratio of eicosapentaenoic acid (EPA)/arachidonic acid (AA) and/or EPA + decosahexaenoic acid/AA after semistarvation therapy.

From the above-mentioned results, we concluded that the increase of platelet aggregability in obese patients after long-term semi-starvation therapy might be due to the increase in the concentration of the proaggregator, $\mathrm{AA}$, in relation to the disaggregators, $\omega-3$ polyunsaturated fatty acids (EPA and DHA). On the other hand, the increase in plasma FFA concentrations observed after the therapy did not seem to contribute to the increase of platelet aggregability after the therapy.

Key words: obesity, platelet aggregation, free fatty acid, eicosapentaenoic acid. 